\title{
Mulher e igreja: a teologia feminista em face católica
}

\author{
Vicente Gregorio de Sousa Filho ${ }^{1}$ \\ Conceição de Maria de Oliveira Miranda ${ }^{2}$ \\ Antonio Michel de Jesus de Oliveira Miranda ${ }^{3}$ \\ Érica Barros de Rodrigues ${ }^{4}$
}

\section{RESUMO}

Neste trabalho se discute a Teologia Feminista, desvelando a participação da mulher na Bíblia, na Igreja e suas relações com a sociedade, a partir de uma perspectiva histórica e teológica. Procuramos nos enveredar pelo tocante à Igreja Católica, onde o feminismo, à luz da Teologia Feminista tem contribuído para uma maior visibilidade da mulher nesta ótica religiosa. Nossa pesquisa possui uma abordagem qualitativa de levantamento bibliográfico que incluiu as narrativas bíblicas, estudiosos da Teologia Feminista e alguns documentos oficiais da Igreja, nos fazendo refletir que as mulheres historicamente têm estabelecido uma íntima relação com o Divino, revelando-o e testemunhando-o em sua vida, mesmo que o ideário patriarcal as tenha tentado intimidar.

Palavras-chave: Mulher. Igreja Católica. Teologia Feminista.

\section{WOMAN AND CHURCH: FEMINIST THEOLOGY \\ IN CATHOLIC FACE}

\section{ABSTRACT}

This paper discusses Feminist Theology, revealing the participation of women in the Bible, in the Church and their relations with society, from a historical and theological perspective. We seek to embark on the Catholic

Doutor em Teologia - Faculdades EST. Professor D.E. IFMA. vicente6@bol.com.br

2 Bacharel em Teologia - UFPI. Professora Ed. Básica - SEDUC -Parnaíba - PI. ceicamiranda@gmail.com

3 Mestrando em Ciências das Religiões - FUV - ES. Professor Ed. Básica - SEMED Tutoia-MA; SEMED - Buriti dos Lopes-PI. educadormichel@gmail.com

4 Mestranda em Ciências das Religiões - FUV - ES. Professora e coordenador de tecnologias educacionais. Prefeitura de Vila Velha -ES. erikinhabarros@gmail.com 
Church, where feminism, in the light of Feminist Theology, has contributed to greater visibility of women in this religious perspective. Our research has a qualitative approach to bibliographic survey that included biblical narratives, feminist theology scholars, and some official Church documents, making us reflect that women have historically established a close relationship with the Divine, revealing it and witnessing it in even though patriarchal ideas have tried to intimidate them.

Key words: Woman. Catholic Church. Feminist Theology.

\section{Introdução}

O livro do Gênesis narra como tudo foi criado por Deus, inclusive homem e mulher. Por primeiro, Ele criou o homem e percebendo que este precisava de uma companheira, criou também a mulher, a nomeando Eva, mãe de todo vivente. Nesta perspectiva criacionista, a mulher foi feita a partir do homem e, há entre os dois semelhanças e diferenças: são distintos, pois cada um assume características próprias que os diferenciam, sejam de ordem biológica ou cultural. São iguais, pois possuem a mesma centelha divina, e o mesmo objetivo de dar continuidade ao plano de amor de seu Criador. Além disso, homem e mulher estabelecem uma relação de reciprocidade na qual cada um descobre a si mesmo no outro (Leonardo BOFF, 2003).

Quando se busca evidenciar esta reciprocidade na trama do tecido cultural da humanidade, historicamente há uma repulsa valorativa por sobre a figura feminina, e um enobrecimento do homem como progenitor, soberano, desmerecendo o papel social da mulher em todos os contextos. Mas fazendo um recorte e colocando em evidência o contexto religioso cristão, católico, afunilamos nossas discussões, buscando compreender a mulher não somente como coadjuvante, mas também como protagonista na Teologia. Neste sentido, qual a relevância da participação de mulheres na história do cristianismo à luz da Igreja Católica?

Em face das questões levantadas, convém discutir como a mulher, obra divina que integra a criação, tem estabelecido diferentes relações sociais ao longo da história, à luz da Teologia Feminista, procurando a compreensão, a partir do prisma católico, da participação feminina no tecido teológico, buscando destacar, nesta perspectiva, seu rompimento 
com a submissão imposta pelo patriarcalismo, dando notoriedade à mulher na fé Católica.

Assim, consideramos relevante alcançar o seguinte objetivo geral: identificar a relevância da participação de mulheres na história do cristianismo à luz da Igreja Católica. E, para melhor detalhamento desta pesquisa, estruturamos os seguintes objetivos específicos: compreender, a partir de um referencial histórico cristão, bem como, a partir de uma literatura feminista, o papel social feminino; e analisar os fatores históricos e ideológicos que levaram à constituição da Teologia Feminista dentro do cristianismo, por vias do catolicismo, desvendando motivos pelos quais esse campo de estudos teológico torna-se relevante.

Metodologicamente optamos por realizar um estudo bibliográfico com uma abordagem qualitativa, utilizando durante a pesquisa uma linha de autores ligados a uma análise teológica da mulher e do feminino.

\section{A teologia e o feminino: uma nova hermenêutica}

Desde meados do século XX, "a sexualidade tornou-se objeto privilegiado do olhar de cientistas, religiosos, psiquiatras, antropólogos, educadores, passando a se constituir, efetivamente, numa 'questão' (LOURO, 2004, p. 27)."

Fazer da sexualidade uma "questão", como nos aponta Louro, significa refleti-la de maneira crítica, problematizá-la. Isso por que ao longo do tempo a sexualidade humana sempre foi alvo de controle, pois era considerada um elemento potencialmente desmoralizante.

Neste sentido, instituições sociais como a Igreja, a Família e o Estado, utilizaram de inúmeros mecanismos para normatizar a sexualidade. No tangente ao controle da sexualidade feminina, nosso ponto de discussão, o ideário criado por estas instituições foi denominado, por historiadores e feministas, entre outros pesquisadores das ciências humanas, de patriarcalismo. O patriarcalismo centrava um determinado grupo familiar na figura do homem, foi gestado da sociedade medieval, e trazido para o Brasil no período Colonial, passou por adaptações nos séculos XVIII e XIX com a ascensão da burguesia ao poder, de maneira que ainda hoje seus resquícios podem ser observados (D’INCAO, 2008).

Desde o final do século XIX e principalmente no século XX, entretanto, com o advento do feminismo, as formas de viver a sexualidade 
e as relações de gênero começaram a ser questionadas. Com a inserção feminina no mundo do trabalho e consequente contato com ideias socialistas, comunistas e anarquistas, as mulheres passaram a reivindicar uma participação social ativa dentro da sociedade, e um consequente reconhecimento digno (PINTO, 2015).

De fato, podemos considerar os feitos realizados nos séculos já citados pelas mulheres, como revolucionários, haja vista que eles mudaram substancialmente as práticas sociais contemporâneas. Não queremos afirmar, entretanto, que a opressão feminina chegou ao fim, na atualidade podemos observar mulheres totalmente submissas como se ainda vivessem no patriarcado colonial ao passo que podemos também observar mulheres chefes de família, que por inúmeras razões optam por criar e manter seus filhos sozinhas.

As práticas femininas revolucionárias repercutiram nas mais variadas áreas de conhecimento, inclusive na Teologia, pois esta como ciência que estuda Deus através da experiência humana, não pode se omitir às transformações sociais de seu tempo. Desta feita, desde o século passado, muitas mulheres inseridas em contextos religiosos cristãos lançaram um novo olhar sobre a Bíblia, procurando novos significados em busca de uma recuperação histórica dentro das escrituras sagradas.

As mulheres reivindicavam então o seu reconhecimento como agentes ativas dentro da história do cristianismo, e não apenas como era estabelecido, em caráter secundário. Elas buscavam (re) construir, a partir da leitura da Bíblia, uma identidade própria que fora perdida após séculos de interpretações sexistas/machistas. De acordo com Leonardo Boff (2003) e Elisabeth Fiorenza (1992), o pensamento teológico através dos escritos de Paulo, Santo Agostinho e Santo Tomás, acabou por tentar naturalizar a condição de submissão feminina, como se situações históricas pudessem ser cristalizadas. Dito de outra forma, pudessem assumir um caráter imutável.

Estas mulheres cristãs, como Cady Stanton (1815-1902), Gertrud Heinzelman (1914-1999) e Mary Daly (1928-2010), entre outras, se constituíram em verdadeiras feministas, pois lutavam dentro das estruturas religiosas por condições de igualdade entre homens e mulheres. Esta luta, na visão de Elisabeth Fiorenza (1992, p. 17) seria potencializada 
na medida em que as raízes femininas dentro do cristianismo fossem valorizadas/reconhecidas:

Por conseguinte, uma reconstrução feminista da história cristã primitiva tem não apenas objetivo teórico, mas também prático: visa tanto à crítica cultural e religiosa quanto à reconstrução da história das mulheres como história de mulheres dentro do cristianismo. Busca não só minar a legitimação das estruturas religiosas patriarcais, mas também potenciar as mulheres em sua luta contra as estruturas opressoras.

A análise da Bíblia pelo feminismo compõe-se então num importante contraponto reflexivo, pois se foi através das reflexões acerca das sagradas escrituras que o pensamento patriarcal-cristão foi alicerçado, será sobre novos olhares acerca das mesmas escrituras que um novo pensamento poderá ser gestado. É necessário compreender que o discurso produzido sobre a Bíblia por teólogos não é politicamente neutro, mas sim marcado pela cultura e pelas relações de poder dentro de uma dada sociedade (João Batista LIBANIO, 2007). Portanto, é necessário um rompimento com o ideário patriarcal-cristão para que possam ser (re) produzidos novos conceitos bíblicos.

Para Leonardo Boff (2003, p. 15) a pertinência do tema feminino dentro da teologia se dá para que se respondam as seguintes questões:

Como o feminino, em primeiro lugar, revela Deus? Como Deus, em segundo lugar se revela no feminino? Em outras palavras: como o feminino que conhecemos se constitui em caminho de conhecimento de Deus? E, depois como Deus mesmo pode ser compreendido e se apresenta caracterizado sob traços femininos? Podemos relacionar Deus em termos de "Minha Mãe", como fazemos em termos de "Meu Pai?".

Dentro da abordagem da Teologia Feminista, as mulheres se constituem como teólogas na medida em que estudam as experiências humanas, em especial das mulheres, com Deus. Constituem-se ainda como feministas, na proporção em que lutam pela igualdade de condições do exercício da fé. Os temas Teologia e Feminismo possuem, portanto, uma conexão dialética, pois estabelecem uma interação em que ora se complementam e/ou ora se antagonizam. 
O desenvolvimento de um discurso teológico elaborado por mulheres e distinto, em muitos aspectos, daqueles que escrevem os homens é marcado pela forte influência das ideias feministas. Revisões das interpretações existentes dos textos sagrados e a proposição de novas interpretações são uma constante entre as teólogas feministas. As doutrinas e a organização institucional têm sido alvo de sua crítica. Também os cultos realizados por grupos de mulheres têm se constituído como espaços de contestação e de criação imaginativa de novas formas de relacionar-se com suas crenças. Pode-se dizer que nenhuma área das religiões instituídas deixou de passar pelo crivo crítico do olhar feminista (ROSADO-NUNES, 2006, p. 294).

Embora no início a Teologia Feminista tenha sido composta quase que exclusivamente por mulheres, existe a possibilidade de inserção masculina neste campo de estudo. Evidenciamos ainda que por não ser um discurso neutro, a maneira pela qual homens e mulheres escrevem sobre as relações entre o Feminino e a Teologia, se diferenciam, pois, cada um se influência por experiências e subjetividades próprias. É claro que as mulheres, como vítimas constantes do sexismo religioso, poderão escrever de maneira mais crítica e ousada que teólogos homens, mas estes também podem atingir tal nível, da mesma forma que aquelas podem ingenuamente reforçar o ideário patriarcal-cristão. Assim, a proposta teológica, neste viés, se alicerça na busca da feminilidade do transcender, no sentido do rompimento com as noções patriarcais humanas, atribuídas ao divino.

O caminho da busca das imagens femininas de Deus é percorrido pela teologia feminista, não para sair à procura de um Deus andrógeno, pois o mistério de Deus transcende a realidade humana (e, portanto, a realidade sexual), mas para corrigir e integrar a linguagem religiosa sexista mais integral e universal, menos inadequada para dar expressão à transcendência. Nesse sentido a teologia feminista fala da recuperação da feminilidade de Deus (GIBELLINI, 2002, p.436)

Podemos considerar, portanto que a Teologia Feminista se ocupa em compreender à luz da Bíblia e da Tradição Cristã a maneira pela qual o feminino se relaciona com Deus, e revela Este no meio da sociedade, desde os tempos bíblicos. Neste processo a desconstrução do pensamento patriarcal-cristão torna-se vital, pois ele sustenta a infe- 
riorização da mulher. Constata-se, então, que as mulheres também são participantes ativas da história da salvação humana.

\section{A Teologia Feminista no contexto dos Estados Unidos e da Europa}

Dentro de nossas analises percebemos a Teologia Feminista em um caráter plural, ou seja, que foi e vem sendo construída com bases em inúmeros discursos.

Uma teologia feminista dita no singular somente é possível se a entendermos como a interação e a convergência de diversas teologias feministas, não como a soma destas, mas em sua complexidade - o que é tecido em conjunto, num tecido de muitas cores (STRÖHER, 2009, p. 508).

Somente com base nessa concepção interacionista poderemos continuar nos referindo, dentro deste trabalho, à teologia feminista no singular. Ainda sob um ponto de vista plural, destacamos que não podemos afirmar que a evolução da teologia feminista ocorreu de forma única no mundo inteiro, por isso, primeiramente refletiremos sob o surgimento deste campo de estudo na realidade europeia e norte-americana, para posteriormente refletirmos sobre os seus desdobramentos dentro do contexto da América Latina e do Brasil.

Historicamente tem-se dividido a história da teologia feminista no primeiro mundo em três fases distintas. Na primeira fase destaca-se a atuação de Elizabeth Cady Stanton que liderava um grupo de mulheres cristãs nos Estados Unidos, que se reuniam para refletir a Bíblia, através da sua condição de mulheres. Como resultado destes estudos foi publicado no final do século XVIII "A Bíblia da Mulher" (The Woman's Bible), que trazia um conjunto de reflexões críticas acerca das leituras bíblicas utilizadas pelos homens cristãos para a legitimação de sua força. Na Igreja Católica, um dos primeiros movimentos em busca da equiparação dos direitos entre homens e mulheres, foi a "Aliança Internacional Joana D'Arc", fundada em 1911 na Grã-Bretanha (SOUZA; SCHMITT, 2018).

Esta primeira fase da Teologia Feminista aproxima-se substancialmente com as reivindicações colocadas pelas primeiras feministas. Destacamos neste sentido que o Feminismo tem origens laicas, e somente posteriormente foi trazido aos limites e possibilidades do cris- 
tianismo. Desta feita, esta primeira corrente concentrava seus objetivos da inserção das mulheres dentro do contexto educacional, através do acesso amplo à escola, do contexto político, com o direito ao voto, e do contexto religioso, através do exercício da função profética da Bíblia. Destacamos ainda que o discurso religioso cristão foi alicerce do patriarcalismo, e como tal necessitava ser contestado para que as mulheres pudessem gozar de uma plena emancipação educativa, política e por fim, religiosa.

O ponto alto da segunda corrente aconteceu durante a realização do Concílio Vaticano II na década de 1960 : um grupo de mulheres lideradas por Gertrud Heinzelman (1914-1999), apresentou um manifesto intitulado "não estamos mais dispostas a calar" (FREITAS, 2003, p. 23). $\mathrm{O}$ manifesto reivindicava o direito de as mulheres também receberem o Sacramento da Ordem, exclusivo aos homens. Este segundo momento foi marcado pela reflexão teológica em torna da possibilidade de ordenação das mulheres. A reivindicação não foi atendida pelo Vaticano II de maneira que ainda hoje se constitui em alvo de discussão entre teólogas (os) feministas. Salientamos ainda que se dentro da ótica católica a ordenação de mulheres ainda se constitui em um tema polêmico (SOTER, 2003), para muitas Igrejas Protestantes já se constitui como uma realidade advinda das lutas de Teólogas Feministas Protestantes.

Após o referido Concílio, podemos encontrar importantes estudos que compõem o cerne das discussões da Teologia Feminista, e de sua terceira fase, também conhecida por "neofeminismo". Entre esses estudos podemos citar a obra "A Igreja e o Segundo Sexo", publicada em 1968 por Mary Daly (1928-2010). A obra faz referência ao livro O segundo Sexo, de Simone de Beauvoir (1967), que se estabelece num marco do feminismo mundial. É na segunda metade do século XX então que a Teologia Feminista toma forma e se consolida, na medida em se constitui pela primeira vez na história como objeto de uma discussão acadêmica, compondo-se num saber mais sistematizado e consequentemente ganhando proporções internacionais, saindo do primeiro mundo e adentrando em diferentes contextos, como o da América Latina, por exemplo (SOTER, 2003). 


\section{A Teologia Feminista no contexto da América Latina e do Brasil}

A história da Teologia Feminista na América Latina e no Brasil ocorreu diferentemente do observado no "primeiro mundo", principalmente pela aproximação destes campos de estudos com a Teologia da Libertação e com as Comunidades Eclesiais de Base (CEB's). Na Europa e nos Estados Unidos a Teologia Feminista relacionava-se diretamente coma as discussões feministas (Maria Clara BINGEMER, 2017).

A Teologia da Libertação trouxe para a reflexão eclesiástica a elucidação da evangélica opção preferencial de Jesus Cristo pelos pobres e oprimidos. Essa reflexão é bastante pertinente ao contexto sociocultural e político da América Latina, haja vista sua histórica exploração econômica e consequente imposição de um centrismo cultural realizada pelas nações do "primeiro mundo".

No contexto latino-americano vale demarcar que este centrismo cultural é o eurocentrismo colonial, masculino, branco, cristão que se estabelece, colocando-se como paradigma cultural, desconsiderando ou mesmo aniquilando a diversidade cultural dos povos originários do continente e de outros povos aqui trazidos, como os negros e as negras (STRÖHER, 2009, p. 510).

Devemos compreender que o contexto Latino é extremamente plural e marcado pela diferença, e a histórica imposição de um centrismo cultural europeu aos povos latinos leva estes, desde as últimas décadas do século XX, a se questionar sobre as possibilidades de sua constituição identitária. A Teologia da Libertação ganhou, pois, ampla aceitação pelos povos latinos, pois esta postula que Deus revela-se nos mais variados contextos e em especial nos oprimidos.

A diversidade de contextos dentro da América Latina fez com que de dentro da Teologia da Libertação brotassem outros campos de estudos, alicerçados por uma ideia de emancipação política, econômica e social, como nos aponta a teóloga feminista negra Sílvia Regina de Lima Silva (2010, p. 83-84):

A produção teológica de mulheres na América Latina, especialmente em seus primeiros anos, tem sido um espaço de diálogo entre a produção teológica acadêmica e os movimentos femininos de organizações populares e eclesiais. Isso também caracteriza a experiência da Teologia Negra [...] 
Esse processo de reflexão coletiva foi marcado por espaços de reflexão e encontros nos níveis regional, nacional e continental, que reuniam teólogas, animadoras comunitárias, professoras de teologia e pastoras. O início da reflexão teológica das mulheres ocorre dentro da Teologia da Libertação. Mantendo o mesmo princípio e metodologia da Teologia da Libertação, a Teologia Feminista da América Latina manteve uma estreita relação entre teologia e realidade política, econômica e eclesial. ${ }^{5}$

As mulheres se inserem dentro da ideologia da Libertação, na medida em que se constituem como sujeitas oprimidas pela dominação masculina. Na América Latina e de modo particular, no Brasil, as mulheres foram chamadas a participar ativamente dentro das CEB's, juntamente com negros e negras, índios e índias, operários e operárias, lavradores e lavradoras. Dentro das CEB's os povos oprimidos refletiam sua opressão à luz da Bíblia. Segundo Elisabeth Fiorenza (1992) a hermenêutica da Libertação deve compreender que nas raízes bíblicas da opressão encontra-se também a fonte de poder dos oprimidos.

A Teologia Feminista Latino-Americana é uma teologia comprometida com a vida e a luta das mulheres. Faz uma crítica às teologias que legitimam de alguma forma a discriminação e subordinação das mulheres nas Igrejas, religiões e sociedades. Relê a Bíblia e as diferentes tradições religiosas a partir da realidade de sofrimento e das perguntas levantadas pelas mulheres no contexto que vivem. É uma teologia plural, feita em comunidade e em diálogo com outras teologias que partem do mundo das/os oprimidas/os. (SILVA, 1994b, n.p.).

O contexto extremamente pobre e oprimido da América Latina levou as mulheres a não só questionar sua condição feminina de inferioridade, mas também a perceber que outros sujeitos compartilham de

5 Traduzido do original: La producción teológica desde las mujeres en América Latina, sobretodo en sus primeros anos, ha sido un espacio de diálogo entre la producción teológica académica y los movimientos de mujeres de las organizaciones populares y eclesiales. Eso caracteriza también la experiencia de la Teología Negra [...] Este proceso de reflexión colectiva estuvo marcado por espacios de reflexión y encuentros a nivel regional, nacional y continental, que reunía a teólogas, animadoras de comunidades, profesoras de teología y pastoras. El inicio de la reflexión teológica desde las mujeres se da en el interior de la Teología de la Liberación. Guardando el mismo principio y metodología de la Teología de la Liberación, la Teología Feminista Latinoamericana ha mantenido una estrecha relación entre la teología y la realidad política, económica e eclesial. 
sua história. Neste sentindo, a Teologia Feminista Latina aproxima-se estreitamente com a luta pela garantia dos direitos humanos e emancipação cidadã dos sujeitos latinos.

\section{As figuras femininas da Bíblia: arquétipos de um passado presente}

Sabemos que a Bíblia se constitui num artefato cultural e político que foi construído historicamente no seio da sociedade judaica e posteriormente pelos cristãos primitivos (CANDIOTTO, 2008). Ela representa a revelação de Deus mediada por práticas e discursos humanos. Assim, retrataremos, brevemente, algumas personagens femininas da Bíblia, buscando compreender as maneiras pelas quais essas mulheres acreditaram e testemunharam Deus em suas vidas, representando ao longo dos séculos (e ainda representam na contemporaneidade) arquétipos que mostram a multiplicidade de possibilidades de experiências com Deus.

Entre as mulheres da sagrada escritura, na tradição cristã europeia e Latina, é conferido a Maria, mãe de Jesus, lugar de destaque, a partir de uma antítese ideológico-religiosa, com Eva, que mais à frente retomaremos de forma minuciosa. Entretanto, há outras que também fizeram de suas vidas um lócus de revelação divina:

Ao longo de toda a Antiga Aliança a missão de Maria foi preparada pela missão de santas mulheres. No princípio esta Eva: a despeito de sua desobediência, ela recebe a promessa de uma descendência que será vitoriosa sobre o Maligno e a de ser mãe de todos os viventes. Em virtude dessa promessa, Sara concebe um filho, apesar de sua idade avançada. Contra toda expectativa humana, Deus escolheu o que era tido como impotente e fraco para mostrar sua fidelidade à sua promessa: Ana, a mãe de Samuel, Débora, Rute, Judite e Ester e muitas outras mulheres. (CATECISMO DA IGREJA CATÓLICA, 2000, p.138).

Dentre as mulheres acima citadas, pertencentes à Antiga Aliança, destacamos a atuação de Rute, Judite e Ester, seus nomes são títulos de três livros bíblicos que pertencem ao conjunto denominado de "Livros Históricos". Durante todo o cânon do Antigo Testamento são apenas estes três livros que recebem nomes femininos mostrando um claro esquecimento e/ou ocultamento das histórias das mulheres na Bíblia. Sobre estes relatos, Carlos Ignácio González (1997, p. 43) comenta que: 
Estes três livros têm vários elementos em comum: apresentam-nos casos de vocações femininas: três mulheres de caráter e personalidade muito diversas, em circunstâncias das mais divergentes, participam de maneiras distintas no plano salvífico divino; mas também colocam bem a claro que foi apenas a mão de Javé que as escolheu e guiou para o bem de seu povo. Portanto, nos três casos aparece a mulher, como mediadora do Senhor, na realização do projeto divino em favor de Israel.

Devemos considerar que embora sejam minoria, os papeis sociais desempenhados por Rute, Judite e Ester estão situados dentro do contexto das narrativas bíblicas que objetivam trazer reflexões morais e éticas sob um prisma religioso, tais reflexões constituíram-se em elementos marcantes para a construção cultural e política do povo judaico-cristão. Portanto as histórias desses povos também possuem reflexos femininos. Os relatos de Rute (4, 11-15), Judite (16, 25-31) e Ester (8, 3-8; 9, 12 14) revelam que aquelas que aguardam e confiam no Senhor não são por Ele desamparadas, mas sim agraciadas.

No Novo Testamento encontramos também a figura Isabel, prima de Maria, que engravida mesmo em idade avançada ( $L c$ 1, 36-45). A viúva que ofertou tudo que tinha (Mc 12, 41-44). A sábia Maria, irmã de Marta, que escolheu a melhor parte, ouvir as palavras de Jesus (Lc 10, 38-42). Tantas pecadoras redimidas que acolheram a palavra de Jesus e tornaram-se fieis discípulas (Lc 8, 1-3). Entre essas pecadoras destacamos Maria Madalena que tendo acompanhado Cristo até a crucificação (Jo 19, 25), recebeu Deste a primeira aparição após sua morte (Jo 20, 14-17) e tornou-se, pois, a primeira a anunciar o Cristo ressuscitado (Jo 20, 18).

Nas narrativas da Nova Aliança tomemos Maria Madalena para ocupar papel de centralidade em nossas reflexões, muito da história dela fora ocultada seja pela não inclusão dos livros apócrifos no cânon do Novo Testamento, seja pela falta de interesse em manter viva as narrativas desta e de outras mulheres. Contudo, atualmente, Madalena também se tornou alvo de discussão teológica. João Paulo II assim a retrata em Mulieris Dignitatem (MD 16):

[...] ela é chamada também "a apóstola dos apóstolos". Maria Madalena foi a testemunha ocular do Cristo ressuscitado antes dos apóstolos e, por essa razão, foi também a primeira a dar-lhe testemunho diante dos 
apóstolos. Este acontecimento, em certo sentido, coroa tudo o que foi dito em precedência sobre o ato de Cristo de confiar as verdades divinas às mulheres, de igual maneira que aos homens $(\mathrm{J} 13,1)$.

Desta feita, constatamos que Maria Madalena torna-se arquétipo salvífico para qual todos nós homens e mulheres somos chamados, haja vista o fato dela saindo de sua condição pecaminosa, aceitou as palavras de Jesus, seguindo seus passos até a cruz, e foi chamada por Ele. A ela foi confiada a notícia da ressurreição de Cristo e após a subida Deste aos céus, ela continuou perseverante na fé (At 1, 14).

Percebemos, portanto que embora ocultadas pelas interpretações androcêntricas da Bíblia, as mulheres fizeram e fazem parte da história da redenção/salvação humana, não como agentes passivas, mas sim como construtoras do Reino de Deus. A pluralidade de mulheres no Antigo Testamento, e ainda daquelas que cercavam Jesus, leva-nos a compreender que a mulher, partilhando de uma essência Divina, pode comunicar, testemunhar e vivenciar Deus dentro de nossa sociedade.

\section{Antítese feminina do bem e do mal no cristianismo}

A compreensão teológica é marcada por antíteses: o bem e o mal; anjos e demônios; Deus e o diabo; céu e inferno; o divino e o profano; o justo e o pecador. $\mathrm{O}$ recorte desta compreensão para a temática do feminino, leva-nos a identificar, uma dicotomia, na história da cristandade, Eva, mulher pecadora e Maria, concebida sem pecado. Esta relação é explicitada em Mulieris Dignitatem:

O confronto Eva-Maria retorna constantemente no curso da reflexão sobre o depósito da fé recebida da Revelação divina, e é um dos temas retomados frequentemente pelos Padres, pelos escritores eclesiásticos e pelos teólogos. [...] surge à primeira vista uma diferença, uma contraposição. Eva, como "mãe de todos os viventes" (Gên 3, 20), é testemunha do "princípio" bíblico, no qual estão contidas a verdade sobre a criação do homem à imagem e semelhança de Deus e a verdade sobre o pecado original. Maria é testemunha do novo "princípio" e da "nova criatura" (cf. 2 Cor 5,17$)$. Melhor, ela mesma, como a primeira redimida na história da salvação, é "nova criatura": é a "cheia de graça". (MD 11). 
As histórias destas personagens e as maneiras pelas quais vivenciaram Deus em suas vidas marcaram profundamente a vida de todas as mulheres ocidentais, de maneira que ainda hoje elas constituem-se em alvos de discussão teológica.

Para que possamos compreender o ideário pecaminoso gestado em torno de Eva, faz-se preciso que retornemos ao contexto da criação, pois é principalmente os relatos do livro de Gênesis que alicerçam a misoginia judaico-cristã. Para tanto consideremos inicialmente os seguintes relatos:

O Senhor Deus tomou o homem e o colocou no jardim do Édem, para o cultivar e guardar. [...] O senhor Deus disse: "Não é bom que o homem esteja só; vou dar-lhe uma ajuda que lhe seja adequada. [...] Então o senhor Deus mandou ao homem um profundo sono; e enquanto ele dormia, tomou-lhe uma costela e fechou com carne em seu lugar. E da costela que tinha tomado do homem, o Senhor Deus fez a mulher, e levou-a para junto do homem. (Gn 2, 15-22).

A serpente era o mais astuto de todos os animais dos campos que o senhor Deus tinha formado. Ela disse a mulher: "É verdade que Deus vos proibiu comer do fruto de toda árvore do jardim?" A mulher respondeu-lhe: "Podemos comer do fruto das árvores do jardim. Mas do fruto da árvore que está no meio do jardim Deus disse: Vós não comereis dele, nem o tocareis, para que não morrais". - "Oh não! - tornou a serpente - vós não morrereis! Mas Deus sabe que, no dia em que dele comerdes, vossos olhos se abrirão, e sereis como deuses, conhecedores do bem e do mal." A mulher, vendo que o fruto da árvore era bom para comer, de agradável aspecto e mui apropriado para abrir a inteligência, tomou dele, comeu, e o apresentou a seu marido, que comeu igualmente. (Gn 3, 1-6).

Sobre estes relatos, São Paulo nos adverte: "Pois, o primeiro a ser criado foi Adão, e depois Eva. E não foi Adão que se deixou iludir, e sim a mulher que enganada, se tornou culpada de transgressão" (1 Tim 2, 13-14). São, pois estes dois argumentos que fundamentam o pensamento misógino: a ordem da criação, primeiro o homem (Adão) e depois a mulher (Eva) e o fato de ter sido Eva a primeira a comer do fruto proibido e posteriormente oferecer este a Adão.

Além da passagem paulina citada, muitas outras (como em 1 Cor.11, 7-9 e 1 Tim 2, 13) fazem referência ao contexto da Criação e ao relato do Pecado Original para afirmar que a mulher deve ser obe- 
diente, subserviente ao homem. Também foi atribuída à mulher uma "essência" pecaminosa, a mulher ao aceitar os conselhos da serpente parece incorporar as características desta, e doravante foi considerada astuta e dissimulada. Assim, "a serpente e Eva não são arquétipos confusos da mística cristã, mas, sim, uma configuração arquetípica dramática moldada pela política patriarcal” (BONETTI, 2013, p. 193).

Presumia-se que se a primeira mulher cometeu tal infração todas guardariam em si o mesmo desejo de sobrepor-se ao universo masculino. $\mathrm{O}$ pecado de Eva seria, no final, um pecado feminino e que não apenas condenava este sexo e tornava sua natureza perversa indiscutível, mas da mesma forma isentaria o homem de responsabilidades sobre a expulsão do Paraíso, ou ao menos minimizaria sua participação no evento (FERREIRA, 2012, p.61).

Contudo, não consideramos que a mulher tenha tais características - alicerçadas pela alegoria da serpente e Eva - como um resultado natural, como uma essência inata que se desenvolve em todas as mulheres. Acreditamos antes que esta concepção pecaminosa de Eva e a extensão de tais características a todas as mulheres foram construídas socialmente através dos discursos propostos por São Paulo, Santo Agostinho e São Tomaz de Aquino, dentre outros pensadores que influenciaram os estudos teológicos.

Para tanto, retomamos as ideias de Elisabeth Fiorenza (1992), para afirmar que essas interpretações misóginas trazem consigo a percepção de mundo de seus formuladores, que como homens, estavam inclinados a manter a situação sexista, na qual a mulher deveria ser subordinada ao homem. É bem verdade que também em Gênesis $(3,16)$, Deus estabelece que a mulher como consequência de sua desobediência deverá se submeter ao domínio do homem, mas também não podemos nos esquecer de que o próprio Jesus destacou a dureza dos corações dos homens (Mt 19, 8) na Antiga Aliança, a ponto de poderem abandonar suas mulheres. Essa passagem do Novo Testamento instiga-nos ainda mais a pensar as maneiras pelas quais o desejo do homem em manter sua hegemonia influenciou as interpretações bíblicas.

Mas não podemos também deixar de salientar que no ato da criação, Deus estabelece entre Adão e Eva uma relação de igualdade, aben- 
çoando a ambos. Neste sentido consideremos esta descrição: "Então Deus disse: "Façamos o homem à nossa imagem e semelhança" [...] Deus criou o homem à sua imagem e semelhança; criou-o à imagem de Deus, criou o homem e a mulher. Deus os abençoou [...]" (Gn 1, 26-28, grifo nosso).

Esta relação de igualdade, afirmada por nós, se reflete no fato de Adão e Eva serem feitos a imagem e semelhança de Deus. O relato bíblico, acima citado, também tem gerado dúvidas entre alguns estudiosos das religiões, pois ele deixa margens para que interpretemos que homem e mulher foram criados concomitantemente, e não em ordem separada. Sobre esta versão, a pesquisadora portuguesa Silvana Mota Ribeiro (2000, p. 8) traz-nos a seguinte reflexão:

A história da Criação aparece ao longo do Cristianismo como justificadora da submissão da mulher face ao homem. O Génesis oferece duas versões da Criação de Eva. Na primeira, homem e mulher são criados como iguais, a partir do pó. Porém, na segunda, Adão é criado em primeiro lugar e uma "auxiliar" surge a partir da sua costela. Será importante não esquecer a problemática à volta da possível contradição entre estas duas histórias. Alter (in BAL, 1987) procura uma explicação para esta aparente incoerência afirmando que os autores da Bíblia terão assumido que Deus criou homem e mulher iguais (Gen. 1), porém, verificando que, na sociedade, não existiria tal igualdade, teriam optado por incluir a versão sexista do Génesis 2 .

Na Carta Apostólica Mulieris dignitatem (1988), João Paulo II reconhece a existência de dois relatos para a criação do homem e da mulher, contudo esclarece que não há contradição entre os dois, e sim uma complementaridade. Ainda neste documento, a Igreja reafirma que ambos, homens e mulheres, foram criados à imagem e semelhança de Deus.

Neste primeiro momento de análise, partiremos do segundo relato da criação, na qual o homem é criado primeiro e posteriormente a mulher. Convém destacar mais uma vez que nossas reflexões têm por base o construcionismo social, que concebe, como elementos instaladores do pensamento misógino, os discursos e as práticas dos homens, ou seja, as representações destes acerca das mulheres.

Conforme nos revela a Constituição Pastoral Gaudium et Spes, podemos considerar que ambos, Adão e Eva abusaram de sua liberdade 
e mesmo que incentivados pelo demônio, optaram por comer do "fruto proibido", devendo os dois serem dignos de culpa, e não somente Eva, como muito foi historicamente reforçado dentro da Igreja:

O homem, contudo, instigado pelo Maligno, desde o início da história abusou da própria liberdade. Levantou-se contra Deus desejando atingir seu fim fora dele. Apesar de conhecerem a Deus, não o glorificaram como Deus. $\mathrm{O}$ seu coração insensato se obscureceu e eles serviram à criatura ao invés do Criador (GS 13).

Ora, então podemos estabelecer um fato: Eva utilizou-se de seu livre arbítrio e decidiu comer do fruto da árvore do bem e do mal. Da mesma forma não podemos inocentar Adão, que se utilizou com igual força do direito Divino do livre arbítrio e decidiu comer do fruto. Por mais que Eva o tenha oferecido, ele poderia ter recusado, mas não o fez. Ambos tomaram suas próprias escolhas.

Agora façamos outra análise. Para tanto, consideramos o seguinte relato de Silvana Ribeiro (2000, p. 11, grifo nosso):

Como seria possível alterar todo o cenário mostrando que, nestas passagens da Queda Original, podemos ver uma manifestação da inteligência feminina e da estupidez masculina. Em Génesis 3: 1, a primeira referência vai para a serpente que é descrita como o mais astuto de todos os animais. Ainda que admitíssemos que a mulher se deixa enganar, teríamos que considerar a astúcia do "enganador".

A pesquisadora portuguesa destaca a estupidez masculina, pois enquanto Eva fora enganada pelo mais astuto dos animais, Adão foi enganado por aquela que foi feita para ser sua companheira, ambos feitos à imagem e semelhança do mesmo Criador. As interpretações bíblicas parecem não atentar para a situação de que Eva foi uma vítima da serpente, foi mais enganada do que Adão. Na contramão desta reflexão, a tradição androcêntrica da Bíblia tem destacado Adão (o homem) como grande vítima, digno de pena por ter sido ludibriado pela fala da mulher (Eva). Verificamos então nesta crítica a manutenção da sociedade centrada na autoridade do homem. A Igreja reconhece em (MD 9) que ambos, homem e mulher, são culpados e marcados pelo pecado original. 
Torna-se imperioso que esclareçamos que não faz parte de nossos objetivos desconstruir ou descartar a pertinência das revelações bíblicas, estamos apenas lançando nosso olhar teológico sobre as escrituras sagradas em busca de novos significados. Contudo, constitui-se verdadeiramente, como nossa intenção, mostrar que dentre as variadas interpretações que o relato da criação pode assumir, foi escolhida aquela que contribui para o estabelecimento da ordem masculina. Acreditamos ainda que esse fato não decorra do acaso. Há fortemente, nesta decisão, o pujante desejo daqueles que detinham o poder na sociedade judaica e nas comunidades cristãs primitivas.

De tal modo, combatemos a percepção histórica essencialista/inata de mulher como pecadora e falsa, consideramos que essas características ganharam status hegemônico e universal através das representações sociais gestadas pelos homens a partir de suas interpretações sexistas da Bíblia. Se para muitos o pecado de Eva pode ser considerado como uma maldição para toda a humanidade, para as mulheres esse castigo foi ainda pior, visto que ainda hoje as mulheres sofrem sanções sociais. Já foi alvo de reflexão neste trabalho o fato da misoginia cristã, que alicerçada no pecado de Eva, constitui-se em elemento estruturante do patriarcalismo.

Ao término de nossas reflexões iniciais sobre o papel de Eva, convém anunciarmos que tem sido recorrente nas reflexões teológicas a afirmação de que tanto Eva como Adão, na verdade, ao trazer o pecado para a humanidade, cumpriram um papel importantíssimo na história da salvação, pois, após esta queda veio uma graça ainda maior, encarnada em Cristo, nascido de Maria. Como São Paulo nos fala, "onde abundou o pecado, superabundou a graça" (Rm 5, 20). Assim sendo, tomando as expressões "abundou o pecado" que é referente à figura pecaminosa de Eva e, "superabundou a graça", referente à vinda do Salvador ao mundo, por outra mulher, Maria, percebe-se, agora com a mãe de Cristo, o avesso da figura de Eva. Portanto, cabem reflexões, mesmo que breves, sobre Maria.

Apresentações acerca de Maria são extremamente desnecessárias, pois desde a Idade Média e principalmente no contexto sofrido da América Latina, o culto a Maria é bastante difundido. Não é difícil encontrar em um ou outro lar católico, uma imagem de Maria, às vezes 
próxima de outro Santo (a) de devoção particular, mas ela também se faz presente.

Neste sentido, em nossa abordagem não pretendemos explicitar fatos históricos acerca de Maria, sua trajetória e vida, mas sim refletir teologicamente sobre os papeis sociais que a bem-aventurada tem inspirado em nossa sociedade. Desta feita, primeiramente retomaremos a questão de que Maria ao longo da história do Cristianismo tem representado aquilo que a mulher deve ser, enquanto Eva assumiu aquilo que a mulher é: pecadora. Logo podemos concluir que a mulher, através da devoção cristã, deveria sair de sua condição pecaminosa (herança de Eva) e encontrar-se com Deus, a exemplo de Maria.

Com efeito, uma ouviu a sentença divina: «Darás à luz no meio de penas»; a outra ouviu, por seu turno: «Alegra-te, oh Cheia de Graça». À primeira disse-se: «Inclinar-te-ás para o teu marido», mas à segunda: «O Senhor está contigo» [...] Que a criação inteira se alegre e festeje, e cante a natividade de uma santa mulher, porque ela gerou para o mundo um tesouro imperecível de bondade, e porque por ela o Criador mudou toda a natureza num estado melhor, pela mediação da humanidade. [...] (HOMILIA DE SÃO JOÃO DAMASCENO, Ano 70?, n.p.)

Dentre todas as inspirações que Maria pode causar no processo educativo do "ser mulher", sem dúvidas a maior de todas é a da maternidade. A jovem de Nazaré consagrou-se no pensamento religioso cristão do ocidente como mãe, por excelência, e é sobre este, o papel social materno de Maria, que centraremos nossas análises. Faz parte da perspectiva feminista desconstruir as interpretações androcêntricas no campo religioso, sendo assim, o papel materno de Maria também perpassa por este plano de análise.

Na sociedade patriarcal a mulher deveria ser exclusivamente dedicada ao lar, nas pessoas de seu marido e filhos. Era, portanto, destinada ao espaço doméstico. As críticas feministas não pretendem negar o fato de Maria ter sido mãe, tampouco o fato de esta ter cumprido este papel com amor e dedicação. Contudo, objetiva-se destacar que o papel materno foi reforçado demasiadamente para inspirar nas mulheres a "obediência de Maria", a "dedicação materna de Maria". Desta maneira, a educação feminina era orientada para a postura passiva necessária à 
manutenção do regime patriarcal. Sobre esta perspectiva, e em análise às influências agonizantes do patriarcalismo na sociedade em que vivemos, Silvana Ribeiro (2000, p.17) salienta que:

Mesmo a aparente conquista do mercado de trabalho e a emancipação feminina (a saída para o domínio público) podem ser vistas como universalizações e idealizações do papel de mãe. As profissões em que o sexo feminino é maioritário reproduzem as funções que as mulheres ocupavam anteriormente no lar, remetendo-as para um estereótipo feminino prescritivo e que as confina impreterivelmente ao contexto familiar e maternal.

Ao realizar essa crítica reprodutivista, a Teologia Feminista também elucida um novo olhar sobre a função de Maria, na construção do Reino de Deus, destacando-a como legítima Apóstola de Cristo. Assim, várias citações bíblicas podem ser utilizadas para comprovar a importância teológica de Maria. Podemos começar com o clássico episódio das Bodas de Caná, "Fazei tudo o que ele vos disser" (Jo 2, 5), esta frase parece ainda ecoar na Igreja, Maria, a ser venerada perante a fé católica, continua a inspirar nos corações dos fiéis, a fé em Cristo.

Maria foi seguidora de Jesus, que enfatizou o fato de que aqueles que fazem a vontade de Deus é que fazem parte de suas famílias (Mc 3, 31-35). Ora, nesta passagem Jesus não retira o destaque de mãe que Maria possui, pelo contrário, reforça-o, pois foi ela, que ao cumprir a vontade de Deus, disse sim, e permitiu a vinda do Salvador, Cristo, o Senhor.

Maria como parte da família de Deus, vivenciou plenamente a Fé em Deus, pois como fala Isabel "bem-aventurada és tu que creste" (Lc $1,45)$ com igual verdade o Anjo Gabriel proclamou "Ave, cheia de graça" (Lc 1, 28). Maria é, portanto, aquela que antes de tudo, inclusive da maternidade, confiou em Deus e por isso encontrou graça diante Dele.

Ela, dentro dos limites de sua humanidade, viveu um amor divino. Fez-se santa, fez-se grande entre os pequenos, por que em sua humildade, soube acolher a vontade de Deus. Na fé católica, ela é sinal de esperança entre os oprimidos, ela é testemunha de que aqueles que esperam em Deus não são por eles abandonados.

Desta santidade divina e humana de Maria resulta sua eminente dignidade que a coloca acima de todas as criaturas, só comparável com aquela de Cristo. [...] vividas na opacidade de uma vida corriqueira, numa minús- 
cula vila da Galileia e depois numa pequena cidade à margem do Lago de Genesaré, Cafarnaum. (Leonardo BOFF, 2003, p. 177).

Mesmo em face da opressão imposta pelo patriarcalismo judaico, Maria teve um papel ativo na experiência humana de Cristo, ela não se restringiu ao lar, pelo contrário, esteve presente como seguidora do Messias, acompanhando-O até o calvário. Ela viveu se desprendendo da única possibilidade que lhe era ofertada como mulher: a experiência materna, restrita ao espaço doméstico. Ela foi às ruas, foi peregrina da fé, deixou-se guiar pelo amor. Como Cristo, fez de sua humanidade uma experiência divina.

Eva e Maria, antítese do bem e do mal, com suas raízes fortemente fincadas no Gênesis e no seio da tradição judaico-cristã. Eva, mãe de todo vivente, também "mãe do pecado"? Foi sobre a sombra de Eva que a mulher se tornou alvo de controle nas sociedades patriarcais, as interpretações androcêntricas da Bíblia encontram nesta a força para a construção de tal verdade. Entretanto, em nossas analises bíblicas, temos tentado provar o contrário, reafirmando a igualdade entre homens e mulheres. Mas, por que então essas relações assimétricas passaram a existir? Elas de fato são resultados do pecado original, no sentido de que a partir de então, o homem e a mulher passaram a conhecer o bem e o mal, se afastando de Deus. A culpa original promoveu um desequilíbrio das igualitárias relações varão-mulher proposta por Deus: "A descrição bíblica do Livro do Gênesis delineia a verdade sobre as consequências do pecado do homem, como indica também a perturbação da relação original entre o homem e a mulher que corresponde à dignidade pessoal de cada um deles". (MD 10).

Conforme João Paulo II propõe em Mulieris dignitatem, mesmo conhecendo a Deus, homem e mulher decidiram distanciar-se Deste, passando a construir estas relações entre dominador e dominada. É, portanto nas relações sociais que a humanidade rompe com o projeto da criação, rompendo com o projeto de seu Criador, estabelecendo essa hierarquização social que fere a dignidade da mulher. Ainda segundo João Paulo II sempre que ferimos a dignidade humana, nos distanciamos ainda mais de Deus. Por isso em Mulieris dignitatem o foco está em recuperar a dignidade feminina, em respeito à sua condição. 
$\mathrm{Na}$ economia da salvação, o próprio Deus quis restabelecer esta ordem da criação, conforme nos aponta a Constituição Dogmática Lumen gentium: "Quis, porém, o Pai das misericórdias que a encarnação fosse precedida pela aceitação daquela que era predestinada a ser Mãe de seu filho, para que assim como a mulher contribui para a morte, a mulher também contribuísse para a vida". (LG 56).

Assim, ampliando esta reflexão, percebemos que da mesma forma em que homem e mulher, nas pessoas de Adão e Eva, trouxeram o pecado ao mundo, foi através do masculino e do feminino que a humanidade se encontrou novamente com Deus, desta vez nas pessoas de Jesus e Maria. Portanto, Deus restaurou a ordem, redimindo a todos, homens e mulheres igualmente. Maria, a nova Eva e Jesus, o novo Adão, ambos personagens fundamentais na história da redenção humana.

\section{Considerações finais}

Antes de tudo, gostaríamos de evidenciar que nossa abordagem não teve por objetivo esclarecer todos os fatos e tampouco superar ou exaurir todas as linhas de reflexões sobre esta temática. Pretendemos contribuir para a intensificação do debate em torno da participação da mulher na tessitura teológica cristã, em meio à forte base ideológica patriarcal, que tentou camufla-las.

Mulher, mulheres, singulares e plurais. A categoria mulher é marcada por mecanismos de hierarquização que buscam naturalizar uma essência de submissão. Contudo, longe dos domínios essencialistas/ naturalizantes, as mulheres são sujeitos históricos e culturais e por isso mesmo transmutam na medida em que a sociedade muda. Essas transformações sociais na história das mulheres em âmbito macropolítico também repercutiram na Igreja Católica alterando suas formas de compreensão do feminino, a partir de uma Teologia Feminista.

Esta Teologia Feminista se dedica a resgatar a história das mulheres na Bíblia, lançando outras análises sobre suas vivências, e desta maneira, atingindo outro objetivo importantíssimo; destacar o feminino, também como lócus de revelação divina. Desta forma, as reflexões dos papeis femininos de algumas mulheres como Rute, Judite e Ester e Maria Madalena, leva-nos a concluir que em muito a participação dessas mulheres foi, e às vezes ainda é ocultado na tradição cristã, tendo em 
vista a permanência de traços sociais patriarcais. A construção do Reino de Deus aqui, na terra, perpassa pela superação dessa invisibilidade feminina da Bíblia.

$\mathrm{O}$ antagonismo entre Eva e Maria, principalmente no tocante a estigmatização de Eva, contribui e é sustentação de um pensamento misógino que atribuía ao feminino uma essência pecaminosa. A releitura desta antítese aponta para uma melhor compreensão das funções de Eva e Adão. Ambos, homem e mulher desobedeceram a Deus, ambos foram condenados às dores do mundo, ao sustento pelo suor de seu trabalho, ambos trazem consigo o pecado. Não somente há culpa na mulher, mas em ambos.

Retomamos que, a partir da figura masculina e feminina, a humanidade conheceu o pecado, mas foi também a partir das relações entre homem e mulher, com Deus, nas figuras de Maria e Jesus, que nasceu a Redenção. Muito embora o mesmo pensamento sexista e patriarcal tente mostrar uma figura somente obediente de Maria, ela vai além disso, se colocando como protagonista na Teologia e, assim, não representa aquilo que a mulher "deve ser", como foi (e ainda é) amplamente difundo no patriarcalismo. Acreditamos que a experiência de Maria com Deus está distante dos limites postos por aquilo que caracterizamos como masculino e feminino. Para além desses binarismos sexistas, Maria se posiciona dentro do pensamento religioso Católico como exemplo para toda humanidade.

Acreditamos que a compreensão das revelações divinas é base para a edificação de uma Igreja e de uma sociedade, na qual a mulher seja compreendida socialmente como um ser de direitos e respeitada em sua cidadania, e paralelamente, no tangente à religião, possa também ser entendida nas multiplicidades de relações que ela pode estabelecer com o Divino. Se em igualdade, nós, homens e mulheres, fomos criados, que em igualdade possamos exercer e ser reconhecidos pela nossa fé.

\section{Referências}

BEAUVOIR, Simone de. O segundo sexo: experiência vivida. Tradução Sérgio Milliet. 2. ed. São Paulo: Difusão Europeia de Livro, 1967.

BINGEMER, Maria Clara. Teologia latino-americana: raízes e ramos. Petrópolis: Editora Vozes, 2017. 
BOFF, Leonardo. O rosto materno de Deus: ensaio interdisciplinar sobre o feminino e suas formas religiosas. 9. ed. Petrópolis, RJ: Vozes, 2003.

BONETTI, Maria Cristina de Freitas. O sagrado feminino e a serpente: performance mítica na simbologia das danças circulares sagradas. 2013. Doutorado (Programa de Pós-Graduação em Ciências da Religião) - Pontifícia Universidade Católica de Goiás, Goiânia, GO. Disponível em <http://tede2.pucgoias. edu.br:8080/handle/tede/3618>. Acessado em 31 ago. 2019.

CANDIOTTO, Jaci de Fátima Souza. Teologia na perspectiva das relações de gênero: a contribuição da hermenêutica bíblica. 2008. Mestrado (Programa de Pós-Graduação em Teologia) - Pontifícia Universidade Católica do Rio de Janeiro. Rio de Janeiro, RJ. Disponível em $<$ https://www.maxwell.vrac. puc-rio.br/colecao.php?strSecao=resultado\&nrSeq=12136@1>. Acessado em 31 ago. 2019.

CATECISMO DA IGREJA CATÓLICA. Edição típica vaticana. São Paulo: Edições Loyola, 2000.

DAMASCENO, João. Homilia sobre a natividade de Maria. Ano 70?. Disponível em <http://agnusdei.50webs.com/polef0.htm>. Acessado em 31 ago. 2019.

D'INCAO, Maria Ângela. Mulher e família burguesa. In: DEL PRIORE, Mary (Org.). História das mulheres no Brasil. 9. ed. São Paulo: Contexto, 2008.

FERREIRA, Letícia Schneider. Entre Eva e Maria: a construção do feminino e as representações do pecado da luxúria no Livro das Confissões de Martin Perez. 2012. Doutorado (Programa de Pós-Graduação em História) - Universidade Federal do Rio Grande do Sul. Porto Alegre, RS. Disponível em $<\mathrm{https}: / /$ www.lume.ufrgs.br/bitstream/handle/10183/56574/000859155.pdf $>$. Acessado em 01 set. 2019.

FIORENZA, Elisabeth Schüssler. As origens cristãs a partir da mulher: uma nova hermenêutica. Tradução João Rezende Costa. São Paulo: Edições Paulinas, 1992.

FREITAS, Maria Carmelita de. Gênero e Teologia feminista: interpelações e perspectivas para a teologia. In: SOTER (Org.) Gênero e Teologia: interpelações e perspectivas. São Paulo: Edições Loyola, 2003.

GIBELLINI, Rosino. A teologia do século XX. Tradução: João Paixão Neto. 2. ed. São Paulo: Edições Loyola, 2002.

GONZÁLEZ, Carlos Ignácio. Maria, evangelizada e evangelizadora. Tradução: José A. Ceschin. $2^{\mathrm{a}}$ ed. São Paulo: Edições Loyola, 1997.

LIBANIO, João Batista. Os carismas na Igreja do terceiro milênio. São Paulo: Edições Loyola, 2007.

LOURO, Guacira Lopes. Um corpo estranho: ensaios sobre sexualidade e teoria queer. Belo Horizonte: Autêntica, 2004. 
MURAD, Afonso. O que Maria tem a dizer às mães de hoje. 3. ed. São Paulo: Paulus, 2003.

PINTO, Fabiane Natália de Souza. Duas faces da mulher contemporânea: carreira e maternidade. 2015. Mestrado (Programa de Pós-graduação em Psicologia) - Pontifícia Universidade Católica do Rio de Janeiro. Rio de Janeiro, RJ. Disponível em <https://www.maxwell.vrac.puc-rio.br/colecao.php?strSeca $\mathrm{o}=$ resultado\&nrSeq=25556@1>. Acessado em 30 ago. 2019.

RIBEIRO, Silvana Mota. Ser Eva e dever ser Maria: paradigmas do feminino no Cristianismo. In: IV CONGRESSO PORTUGUÊS DE SOCIOLOGIA, Universidade de Coimbra, 17-19 abr. 2000. Disponível em: <http://repositorium.sdum.uminho.pt/bitstream/1822/5357/1/MotaRibeiroS_EvaMaria_00.pdf $>$. Acesso em 31 ago. 2019.

ROSADO-NUNES, Maria José. Teologia feminista e a crítica da razão religiosa patriarcal: entrevista com Ivone Gebara. Estudos Feministas, Florianópolis, 14(1): 336, janeiro-abril/2006. Disponível em $<$ https://periodicos.ufsc. br/index.php/ref/article/view/S0104-026X2006000100016/7615>. Acessado em 30 ago. 2019.

SILVA, Sílvia Regina de Lima. Abriendo Caminos, Teología Feminista y Teología Negra Feminista Latinoamericana. Revista do Programa de Pós-Graduação em Letras e Ciências Humanas - UNIGRANRIO. v. 1, n.1, 2010. Disponível em <http://publicacoes.unigranrio.edu.br/index.php/magistro/ article/view/1055/618>. Acessado em 31 ago. 2019.

SILVA, Sílvia Regina de Lima. Teologia Feminista Latino-americana. In: II Consulta de Teologia e Culturas Afro-americanas e Caribenhas, São Paulo, 7-11 nov. 1994b. Disponível em <http://ospiti.peacelink.it/zumbi/afro/atab/ cons22.html>. Acesso em 31 ago. 2019.

STRÖHER, Marga Janete. Teologia feminista e gênero - territorialidades, deslocamentos e horizontes. In: Comunicações do III Fórum Mundial de Teologia e Libertação. Belém, 21-25 jan. 2009. Disponível em: <http://scribd. com>. Acessado em 31 ago. 2019.

SOTER, Sociedade de Teologia e Ciências da Religião. Gênero e teologia: interpelações e perspectivas. Belo Horizonte: Edições Loyola, 2003.

SOUZA, Tiago Dias de; SCHMITT, Flávio. Hermenêutica bíblica cristã: abordagens e implicações a partir da teologia feminista. Revista de Cultura Teológica. Ano XXVI, n. 91, jan/jun 2018. Disponível em <https://revistas.pucsp. br/culturateo/article/view/rct.i91.37326/pdf>. Acessado em 30 ago. 2019. 